memorial service was held in Urbana on October 7, 1995. Memorial contributions can be made to the Phillip Monypenny Scholarship Fund, c/o Department of Political Science, 702 South Wright Street, Urbana, Illinois, 61801 .

Stephen A. Douglas

Belden Fields

University of Illinois at

Urbana-Champaign

\section{Edward N. Muller}

Our friend and colleague, Edward N. Muller, died June 3, 1995, taken from us by a tragic accident while engaging in one of his favorite activities, horseback riding in the desert foothills near his house in Tucson, Arizona. All who knew him as a scholar and as a person know his unique qualities and share our loss. He was taken at the peak of an extraordinary career, culminating most recently in his service as Head of the Department of Political Science at the University of Arizona. He will be deeply missed by his loving wife Peggy, his devoted children Nick, Sarah, and Alexandra, and his many friends in the Department and in the profession.

Ned Muller was a great man, a great friend, and a great scholar. He was a leader, not a follower, a doer, not a spectator. He strove for excellence in whatever he set out to do in life, and over the course of his tragically-shortened career he became one of the world's leading scholars in the study of political violence and the stability of democratic regimes. His publications, including one book, fourteen articles in the American Political Science Review, and over two dozen other scholarly articles, greatly advanced our knowledge in these areas of fundamental scientific, politi$\mathrm{cal}$, and social importance. And he inspired his many students and collaborators to strive to attain the high standards of excellence he set for himself.

Ned entered his career in political science, to a certain degree, through the back-door. His undergraduate career at Yale (B.A., Scholar of the House, 1965) was distinguished, but his major field was English literature, not the standard preparatory concentration for the study of political science. He entered our field only after some two years in the prestigious Writers Workshop at the University of lowa, transferring into the Iowa graduate program in political science in 1967. Those faculty members and peers fortunate enough to deal with him, however, recognized as soon as he began that Ned was not your run-of-the-mill disenchanted transferee. Ned rapidly absorbed political science theory and quantitative analysis, and his course to the Ph.D. degree became as direct, as swift, and as studded with scholarly accomplishments as that of any Ph.D. candidate in our collective experience.

While in graduate school, he produced three articles on the crossnational determinants of regime support and civic competence that would appear in major journals (two in the American Political Science Review and one in the Midwest Journal of Political Science). For his dissertation exploring urban racial violence in Waterloo, Iowa, he designed an original survey, trained interviewers, supervised the data collection, analyzed the results and completed the final manuscript-all in less than six month's time. The dissertation, supervised by John Wahlke, would produce a third APSR article two years later. Not four years after he entered the graduate program in political science, Ned left Iowa in 1970 to begin his teaching career at SUNYStony Brook, having already established himself as a young scholar with virtually unlimited potential.

In the ensuing decade, Ned pioneered the survey-based study of political violence in a series of APSR articles and a book, Aggressive Political Participation, published by Princeton University Press in 1979. Using data from surveys that he developed and administered in West Germany and the United States, Ned's work relentlessly subjected the leading theories of participation in political violence to rigorous cross-national empirical tests. He found that neither the then-popular "J-curve Theory" of rising expectations, nor more general theories of relative deprivation, were adequate explanations of individual acts of violent political behavior. Instead, he showed that the fundamental attitudinal factor associated with aggressive participation was an individual's overall alienation from the political regime, and in several important articles Ned outlined new ways of measuring and understanding this "leading indicator" of political violence and regime instability ("Behavioral Correlates of Political Support," APSR 1977; "On the Meaning of Political Support," APSR 1979, with Thomas O. Jukam; and "Diffuse Political Support and AntiSystem Political Behavior: A Comparative Analysis," AJPS 1982, with Thomas O. Jukam and Mitchell A. Seligson). In Aggressive Political Participation, Ned developed a general model that included system alienation, individual beliefs in the utilitarian and normative justification for violence, and facilitative social and community norms as the key determinants of individual protest participation. The book was a model of careful social scientific analysis, and this body of work had enormous influence on the study of protest participation in the ensuing years.

Ned's growing prominence in the profession brought him to the attention of other universities, and in 1977 he accepted an offer to join the University of Arizona. Although an Easterner by birth and conviction, Ned immediately fell in love with Arizona and the American West. This love of the West would manifest itself in many ways: Ned loved to hike and camp, but most of all, he loved to ride his prized horses, often accompanied by his beloved dog Tinsel, in the Arizona desert. Ned enjoyed the desert most from horseback, and he used to say that this beauty inspired him in his writing and his research. His collaborators frequently joined Ned on long walks or rides through the desert, receiving inspiration from the beautiful scenery, and more so from Ned's friendship and intellectual vision for their joint projects. 
While at Arizona, Ned began to sense that micro-level analysis was not sufficient to understand fully the processes of political violence and regime breakdown, and he began a series of macro-level studies of democratic stability that would continue literally until the day he died. This line of research, supported with multiple grants from the National Science Foundation, ultimately would produce approximately one dozen articles in the APSR and in the American Sociological Review, and a dozen other scholarly publications. The work sparked considerable controversy in the major journals of political science and sociology, but indisputably solidified Ned's reputation as one of the leading analysts of cross-national patterns of political violence.

This expansion of focus occurred almost immediately upon arriving in Tucson; indeed its seeds were planted over the course of a lunch with Mitchell Seligson during Ned's job interview at Arizona. Ned immediately recognized the opportunities for comparative work in Latin America, a part of the world in which political stability and democracy long had been in question. Ned saw the region as presenting opportunities for comparative analysis far richer than he had experienced in the U.S. or Europe, and during that lunch he and Seligson sketched out a research program that would initially explore the bases of democratic stability in Costa Rica, Latin America's most stable democracy, but would eventually move beyond that case to more broadly cover the region and other democracies around the world. This research led to many publications, the most important of which showed that the key macrolevel predictor of violence and instability was income inequality, overriding virtually every other macro-level variable in explaining cross-national variations in violence and democratic breakdown ("Income Inequality, Regime Repressiveness, and Political Violence," $A S R$ 1985; "Inequality and Insurgency," APSR 1987, with Mitchell Seligson; "Land Inequality and Political Violence," APSR 1989, with
Seligson and Hung-Der Fu; "CrossNational Variation in Political Violence: A Rational Action Approach," Journal of Conflict Resolution 1990, with Erich Weede; "Inequality and Political Violence Revisited," APSR 1993, with Seligson and William Dixon).

Along with his new-found interest in macro-comparative analysis, Ned continued to make significant contributions to the understanding of protest and violent political participation at the micro-level as well. In the mid-1980s he began collaborative work on political protest with the German sociologist KarlDieter Opp, in which they attempted to explain individual participation by means of rational choice theory. Muller and Opp produced a seminal article on this topic ("Rational Choice and Rebellious Collective Action," APSR 1986), leading directly to their embarking on a large-scale collaborative survey research project examining rational choice and alternative theories of protest in Germany, Peru and Israel. In several more recent articles, Ned and his collaborators claimed that a "public goods" version of rational action theory had greater explanatory power in accounting for protest participation than models based on relative deprivation or the "selective incentives" from Olson's conventional rational choice theory ("Personal Influence, Collective Rationality, and Mass Political Behavior," APSR 1989, with Steven E. Finkel and Karl-Dieter Opp; "Discontent and the Expected Utility of Rebellion: The Case of Peru," APSR 1991, with Finkel and Henry A. Dietz). This work also has generated its share of controversy, but like all of Ned's research, it captured the attention of researchers in multiple disciplines and helped set the terms of ensuing scholarly debates.

In 1993, Ned was selected as Department Head at Arizona, the culmination of his sixteen years of service to the University. He enjoyed enormous success as Head over the next two years, overseeing the rapid rise of the Department in national rankings, recruiting highly promising young scholars, and pro- moting able colleagues through the ranks. The tremendous outpouring of emotion in Tucson in the days after his death attests to the esteem and affection in which he was held by friends, students, and colleagues in the Department and University community.

At the time of his death, Ned was engaged in several important new projects. In collaboration with Seligson, he was attempting to fuse the macro and micro perspectives on political stability that largely had remained analytically, if not theoretically, separate throughout his career. The strategy of this work was to utilize national-level aggregates of survey data in crossnational explanatory models that also included macro-level factors such as income inequality, economic development, and the like. An initial effort in this direction appeared in the APSR in 1994 ("Civic Culture and Democracy: The Question of Causal Relationships," with Seligson). Ned had also nearly completed a second book manuscript, entitled Democracy, Development, and Inequality, which was to represent the culmination of all of his comparative work on inequality, economic performance, and democratic stability. Indeed, only hours before the accident Ned had finished revisions on a number of the book chapters, and it was clear to him that the book was in its final stages. We hope to publish this manuscript posthumously.

Ned Muller conceived of himself as a scientist, struggling to crack the important puzzle of democratic stability. He abhorred dictatorships and wanted to know how democracy could be spread throughout the world, a task that his sudden and unexpected death left him unable to complete. He left behind a challenge for his colleagues and students to achieve the goal he had set out for himself. Among the last words he wrote prior to his death was an expression of deep pessimism regarding the long-term prospects for a more democratic world. Yet he envisioned that policy changes to reduce income inequality could salvage, and indeed extend, democracy for many countries 
around the world. Implementing these changes, and understanding more completely the causes of political violence and democratic breakdown, are tasks well worth our attention as a fitting memorial to one of the great political scientists of our day.

Steven E. Finkel

University of Virginia

Jerrold G. Rusk

University of Arizona

Mitchell A. Seligson

University of Pittsburgh

John Wahlke

University of Arizona

\section{Joann P. Paine}

Joann P. Paine, Associate Professor Emeritus at Southern Illinois University at Carbondale, died on April 11, 1995 in Waldport, Oregon. Joann was born on March 10, 1935, in Portland, Oregon. She earned her bachelor's degree from Whitman College in 1957, and then attended the University of Oregon where she earned her master's degree in 1963 and her Ph.D. in 1967. Like all of us in the academy, Joann "wore many hats" during her professional career. She was a woman, wife, mother, social advocate, contributing colleague, scholar, teacher, and friend.

As a woman, Joann was ahead of her time. She earned her Ph.D. in political science and became a university faculty member when that discipline was still composed almost exclusively of males. She was juggling the roles of "homemaker" and "career woman" long before that balancing act became fashionable. In recognition of her many contributions as a woman, Joann was listed in Who's Who of Young Women in America in 1968, International Who's Who of Women in 1976, and World's Who's Who of Women in 1977 and 1979.

Joann married Thomas Paine on February 2, 1957, in Tacoma, Washington. They were ideally suited for each other, and their marriage lasted until her death some 38 years later. As a wife Joann was always a true compan- ion. In her role as a mother, Joann raised six children-sons Robert, Thomas, Nicholas, and Patrick, and daughters Mary and Elizabeth. She also had seven grandchildren. As a mother she actively participated in all aspects of her children's lives, including serving on the Parent's Committee at her children's elementary school and serving as president of the Parent Teacher Association at her children's junior high school.

Joann was always involved in trying to develop a high degree of social consciousness in her university, profession, and community. As a social advocate within the university, Joann served on the Sexual Harassment Board and the Title IX Compliance Committee on Intercollegiate Athletics. Within the profession, she served on the MWPSA Committee on the Status of Women in the Profession, and within the broader community, her advocacy role included serving on the Steering Committee for Total School Integration.

If there was one thing for which Joann will always be remembered, it is for the seemingly endless energy which she poured into her role as a contributing colleague and member of the university community. In her years as a faculty member in the Department of Political Science at SIUC she served on a great many departmental committees, was the Director of Graduate Studies, and served as the adviser for Pi Sigma Alpha. In addition, she was endlessly giving of her time and talents to the broader university, including long-term service on both the Faculty Senate, many of its subcommittees, and the Student Conduct Review Board.

Joann's scholarly activities are best represented by the book Introduction to Systematic Political Science, which she co-authored with David Everson. That book complemented her role as a teacher, which I am sure she considered her first love (outside of her family). As a teacher she served on a great many master's thesis and Ph.D. dissertation committees, where she spent countless hours with students going over their written products. She was always developing new courses and reading in emerging areas of the discipline that provided her with new intellectual challenges. She enriched our department by developing and teaching a variety of what were then nontraditional courses, including Minority Politics, Urban Politics, Political Violence, and Computer Simulation.

My most vivid memories of Joann relate to her in the role of a friend. Joann began teaching at SIUC one year before me, and when I joined the faculty we very quickly became good friends. In the ensuing years we drank a lot of beer together with our graduate students, both of us believing that out-of-class socialization was an extremely valuable part of graduate education. We shared many concerns during the Vietnam war era, and we groped with the intellectual and ethical realities of the mass demonstrations and closing of the University in 1970. For several years after I joined the faculty at SIUC, Joann's husband Tom played fast pitch softball with me on a team that I managed, and my memory says Joann never missed a game-nor the pizza and beer afterwards. Over the years we enjoyed each other's company at countless departmental socials and graduate student gatherings. Tom and I both enjoyed banging on our guitars and singing folk tunes, and Joann would sit into the wee hours of the morning listening to us display our poor talents and talking with graduate students. She loved her dogs, her orchids, and quilting with the female senior citizens of the community. And some might say that she also just plain loved to "chat"with almost anyone, anytime, about anything.

Indeed, in her many roles Joann touched and made a difference in the lives of a great many persons. She will always be remembered by those who knew her, and will be missed dearly by those who loved her.

Roy E. Miller

Southern Illinois University at Carbondale 